\title{
A sala de aula e a produção de sentido em práticas de letramento na história ensinada
}

\author{
Classroom and the production of meaning in \\ literacy practices in the teaching of History
}

\section{Aula y la producción de sentido en prácticas de alfabetización en la enseñanza de Historia}

\author{
Patricia Bastos de Azevedo* \\ Ana Maria Ferreira da Costa Monteiro**
}

\begin{abstract}
Resumo: O presente estudo buscou investigar a produção de sentido em práticas de letramento na história ensinada, operando conceitualmente com o campo da linguagem a partir do Círculo de Bakhtin. Na perspectiva teórica adotada, os enunciados constituem-se no processo relacional situado, com um pano de fundo sócio-cultural, e o cenário composicional relaciona-se diretamente com o emprego das enunciações e de suas relações intersubjetivas. Nessa perspectiva, a história ensinada é compreendida não só pelas questões disciplinares relacionadas à historiografia, ou, em outras palavras, pela prática de letramento que permeia o exercício do ofício do historiador; mas também compõe-se das dinâmicas de formação e significação do mundo da vida, as quais se fazem presentes no espaço de ensino.
\end{abstract}

Palavras-chave: Ensino de história. Letramento. Produção de sentido.

\begin{abstract}
This study aimed to investigate the production of meaning in literacy practices in History education, conceptually working with the field of language drawn from the Bakhtin Circle. With their theoretical perspective, enunciations are formed within the relational process, with a socio-cultural background, and the compositional scenario is directly related to the employment of enunciations and its intersubjective relations. In this context, taught History is understood not only through disciplinary questions related to historiography, or, in other words, through the practice of literacy that surrounds the work of the historian; but it is also composed by the dynamics of formation and signification of the world of life, which are present in the space of teaching.
\end{abstract}

Keywords: The teaching of History. Literacy. Production of meaning.

Resumen: Este estudio tuvo como objetivo investigar la producción de sentido en las prácticas de alfabetización en enseñanza de Historia, trabajando conceptualmente con el campo del lenguaje extraído del Círculo Bajtín. Con su punto de vista teórico, enunciados

\footnotetext{
* Docente da Universidade Federal Rural do Rio de Janeiro. E-mail: <patriciabazev@yahoo.com.br>

** Docente da Universidade Federal do Rio de Janeiro. E-mail: <anamont@superig.com.br>
} 
se forman en el proceso relacional, con un nivel socio-cultural, y el escenario de composición está directamente relacionado con el empleo de los enunciados y sus relaciones intersubjetivas. En este contexto, la historia que se enseña se entiende no sólo por cuestiones disciplinarias relacionadas con la historiografía, o, en otras palabras, a través de la práctica de alfabetización que rodea el trabajo del historiador, pero también está compuesto por la dinámica de la formación y de la significación del mundo de la vida, que están presentes en el espacio de enseñanza.

Palabras clave: La enseñanza de Historia. Alfabetización. La producción del sentido.

[...] Na realidade existem somente "sentidos atuais", signos empregados concretamente nas situações específicas. Encontramos o signo já usado em determinado contexto comunicativo, com sentido que, por sua vez, conecta-se dialeticamente com o sentido dos contextos próximos ou distantes dos que já haviam sido usados (PONZIO, 2008, p. 92).

\section{Introdução}

A sala de aula, como espaço complexo, múltiplo, híbrido e ambivalente, desperta muitos questionamentos e possibilidades investigativas. Assim, como esse espaço se estrutura no complexo relacional, constitui-se em uma ampla gama de possibilidades interpretativas, compromissos sociais, relações hierárquicas e de poder.

A pesquisa que desenvolvemos em nosso doutorado buscou analisar, nesse amplo leque de possibilidades, uma questão relevante e constitutiva do espaço da prática: a produção de sentido nas práticas de letramento operadas na história ensinada. Vale destacar que a expressão "prática" em nossa pesquisa situou-nos no espaço do fazer em sala de aula e na relação do professor com a disciplina escolar ensinada.

Nesse enquadramento, dimensionamos o foco da pesquisa para a sala de aula de História no tempo de transição entre as séries iniciais do Ensino Fundamental $-1^{\circ}$ e $2^{\circ}$ ciclos de ensino - para as séries finais $-3^{\circ}$ e $4^{\circ}$ ciclos de ensino. Nosso propósito e recorte buscaram investigar o $6^{\circ}$ ano de escolaridade e a singularidade que essa etapa possui na formação dos alunos e na prática do professor de História.

Ao ingressarem no $1^{\circ}$ ano do $3^{\circ}$ ciclo, os alunos são submetidos a uma nova ordem social escolar e têm seu ritmo rompido por múltiplos novos acontecimentos. Nesse momento de suas vidas, conhecem no mínimo oito novos professores, que possuem identidades distintas e formas diferentes de se relacionar com os alunos e com os processos de ensino. Em suma, é um emaranhado de novidades e possibilidades que desafiam professores e alunos. 
Este artigo busca refletir sobre tal singularidade: a sala de aula de História no $6^{\circ}$ ano de escolaridade, focalizando as práticas de letramento e a produção de sentido constituídas nesse processo de ensino.

\section{A história ensinada como espaço de correlações de forças discursivas}

A história ensinada está permeada por questões sócio-históricas e intersubjetivas de seu ato. Em vista disso, a aula está imersa em "determinado contexto comunicativo". E, nesse instante, os sentidos vão sendo tecidos e novas formas de significação vão sendo fixadas, tanto pelo professor, que pode ou não agregar sua concepção de ensino de História, como pelo aluno em relação à história e a sua compreensão de mundo e do passado.

A história ensinada estrutura-se mediante uma cadeia de enunciados já proferidos pelos campos discursivos que a constituem (BAKHTIN, 2003, p. 296). Dessa forma, passamos a compreender o ensinado como uma produção dialógica: suas bases têm existência ou significação sócio-histórica e fundam-se no conhecimento tecido no tempo-espaço.

Na atualidade, ganhar a adesão da turma e sua voluntária participação é o desafio enfrentado pelos professores no fazer cotidiano. Em razão disso, a posição de autoridade inquestionável do professor e da escola está em xeque, obrigando o ensinado a se constituir de forma diferente e a se ressignificar constantemente. Dessa maneira, forças monológicas e dialógicas tensionam o ensinado e seus enunciados proferidos e constituem muitas vezes discursos híbridos e ambivalentes.

Cada palavra implica uma concepção singular do ouvinte, seu fundo aperceptivo, um certo grau de responsabilidade e uma certa distância. Tudo isto é muito importante para se entender a vida histórica da palavra. Ignorar estes aspectos e nuanças conduz à reificação da palavra, à extinção de seu dialogismo natural.

Tudo isto determina os meios de elaboração da palavra interiormente persuasiva em sua transmissão e os processos de seu enquadramento num contexto (BAKHTIN, 1998, p. 146).

Na sala de aula de História, as práticas de oralidade, leitura e escrita são dimensionadas de forma diferente da vida cotidiana e da ciência de origem (em nosso caso, da História). Ademais, as práticas de letramento são um conjunto de signos sociais e, como tal, são constrangidas e cerceadas pelas questões sócio-históricas que permeiam a escola e constituem sua tradição. Como produtoras de cultura, essas práticas extrapolam o espaço físico da escola e compõem a sociedade de sentido e de significação. Todavia, não podemos esquecer ou negar que se trata de uma via de mão dupla, e, como tal, a escola também é impactada pela sociedade e seus diferentes e diversos movimentos culturais. 
A escola, antes "detentora e lugar de propagação" de um saber "legítimo e prestigiado", perde esse status e se vê abalada tanto por novas formas de pensar e fazer leitura e escrita, quanto por promoção do conhecimento contido em outros espaços de divulgação. Nesse sentido, aponta Chartier (2005, p. 22) que:

É preciso reconhecer que a escola, que era o lugar unificador dos conhecimentos, depositária do tesouro dos saberes e guardiã das chaves que davam acesso a eles, está morta; uma escola que oferecia a todos a propriedade por meio do estudo e amor do saber. Ou melhor, está morta esta representação de uma escola que sem dúvida nunca existiu, mas que era suficiente como crença coletivamente partilhada para que ela fosse legítima. Qual pode ser seu novo espaço de ação e seu projeto cultural, como ela pode participar da tarefa, sem negar-se a extensão do termo que designa hoje a "cultura"?

Outras formas de propagação de conhecimento invadem nossa vida cotidiana. A televisão, o cinema, os meios de comunicação de massa e a internet, dentre tantos outros, dimensionam a informação e popularizam o conhecimento. O Google é a grande "enciclopédia" virtual, visto que nele encontramos diversas informações, um espectro quase infinito de referências - seja para o "bem" seja para o "mal", usando uma adjetivação bem contemporânea à nossa sociedade. Nesse emaranhado de novos canais legítimos - muitas vezes não legitimados - de propagação de conhecimento, a escola perde seu lugar e é questionada quanto a sua validade e eficácia. Novos gêneros discursivos são criados e antigos são legados ao ostracismo, esquecimento ou desuso, e a escola, que não caminha no mesmo ritmo que a vida, muitas vezes não incorpora os novos rumos que a leitura e a escrita ganham no mundo da vida.

Somos diariamente invadidos por textos e informações de diferentes estilos composicionais e de campos discursivos múltiplos. Vivemos em uma sociedade - em nosso caso a brasileira/carioca - permeada por práticas de leitura e escrita, em suas diferentes modalidades e composições. Historicamente, essa mudança vem ocorrendo nos últimos cinco séculos, sobretudo a partir da invenção da imprensa em 1453, o que popularizou os materiais de leitura. Assim, construiu-se uma nova forma de ser e estar no mundo, configurando uma nova imagem do ser humano, adensando os condicionantes de status e valorizando ainda mais o "homem letrado". Entretanto, não podemos esquecer que o acesso a esse bem cultural se faz nas relações de poder e, assim, produz "leitores e leitores",textos considerados mais importantes e legítimos e outros sentenciados ao espaço da "sub-cultura" e ao desprestígio.

A escola é atravessada e constituída historicamente por uma versão e uma perspectiva de cultura letrada muito próxima ao legitimado por diferentes grupos que disputam qual conhecimento letrado a escola ensinará. Dessa forma, podemos afirmar que a escola é constituída, em sua tradição, por um letramento "dominante" e legitimado que visa promover uma cultura letrada em detrimento 
de outra. Assim como diferentes meios de promoção cultural, esses também lançam holofotes em uma perspectiva cultural letrada, silenciando e obscurecendo outras possibilidades.

Os atores são desafiados cotidianamente em sua capacidade de letramento e autonomia no uso da leitura, não obstante as práticas de letramento que eles dominam e pelas quais transitam com certa desenvoltura não sejam as eleitas e promovidas pela escola. Não estamos afirmando que deveriam ser, estamos apenas constatando um fato.

Nessa direção, a História ensinada, permeada por questões da construção estilística que compõe o seu fazer, tem seus enunciados constituídos em um campo discursivo que os limita, constrange e tematiza. Está, dessa forma, situada em um tempo-espaço que constrói sua significação dialogando e hibridizando questões da História, da educação, do ensino em ato e da intersubjetividade de seu protagonista - o professor (AZEVEDO, 2010). Este último atua consciente e inconscientemente sobre sua ação, sendo o ensinado tanto fruto de elementos macro e micro no espaço da sala de aula quanto fruto da mobilização de saberes oriundos de múltiplos espaços de formação, reflexão e vida.

\section{O letramento como estruturante do ensinado}

As questões relativas à alfabetização e ao letramento permearam de forma estruturante as mudanças paradigmáticas iniciadas no período histórico dos últimos vinte anos e influenciaram os elementos teóricos e práticos no processo de ensino de forma relevante. É fundamental analisarmos o reflexo que as questões destinadas ao letramento produziram nos saberes e nos fazeres construídos pelos professores no tempo-espaço da história ensinada.

O texto de História, em suas diferentes abordagens e modalidades, diferencia-se das questões centrais da alfabetização no seu sentido mais restrito, isto é, na aquisição de competências que possibilitem a decodificação e a codificação do sistema alfabético. A História ensinada está repleta de expressões e conceitos que os professores, ao longo do ensinado, apresentam aos alunos e assim vão "letrando-os" em um tipo escolar de História e apresentando-lhes uma versão historiográfica do passado. Além disso, compreendemos o letramento como uma relação ampliada das questões relativas à alfabetização pois, ao incorporar questões de oralidade, leitura e escrita, dimensionadas em uma perspectiva social ampla, isto é, em uma perspectiva de sociedade "grafocêntrica" (MORTATTI, 2004), marca de forma relevante e profunda as práticas de letramento que são desenvolvidas em diferentes campos discursivos. 
Os gêneros discursivos estabelecem uma interconexão da linguagem com a vida social. A linguagem penetra na vida por meio dos enunciados concretos e, ao mesmo tempo, pelos enunciados a vida se introduz na linguagem. Os gêneros estão sempre vinculados a um domínio da atividade humana, refletindo suas condições específicas e suas finalidades. Conteúdos temáticos, estilo e organização composicional constroem o todo que constitui o enunciado, que é marcado pela especificidade de uma esfera de ação. (FIORIN, 2008, p. 61-62).

Gostaríamos de destacar que o espaço do ensinado é constituído por questões das práticas de letramento, marcando profundamente a estética composicional das práticas discursivas que habitam a sala de aula e os gêneros que a compõem. Podemos afirmar que as salas de aula, no momento do ensino de História, apresentam atos de oralidade, leitura e escrita permeados pelo signo histórico e por gêneros situados no tempo-espaço sócio-histórico. Sendo assim, as práticas de letramento que habitam a História ensinada, distintas da aquisição inicial da alfabetização, estão entrelaçadas com a dinâmica escolar e com o mundo da vida.

O mundo da vida, a escola e outros espaços letrados nos municiam de elementos para o uso da língua e, dessa forma, oralidade, leitura e escrita encontram-se nesse contexto cultural amplo que nos forma. Dialogando com Mortatti (2004) e concebendo nossa sociedade como grafocêntrica, pressupomos que a leitura e a escrita em diferentes graus estruturam os enunciados dos vários indivíduos que habitam esta sociedade.

A História ensinada, em sua dinâmica cotidiana, depara constantemente com o jogo de poder que a legitima, e o professor, em seu protagonismo relativo, age diante da busca por legitimidade, organizando seus atos de fala, leitura e escrita em sala de aula. O que estamos afirmando é que o ensinado está mergulhado na dinâmica social complexa e situada e é permeado profundamente pelas práticas de letramento em qualquer sala de aula, nos sentidos tecidos nos processos que se estabelecem nessa dinâmica.

\section{A História ensinada como espaço de práticas de letramento}

No terceiro ciclo do Ensino Fundamental, são exigidas dos alunos diferentes formas de falar, ler e escrever. O aluno depara com vários professores que lhe solicitam as práticas de letramento e a autonomia que a grande maioria não consegue desenvolver.

Ler e escrever no terceiro ciclo do ensino fundamental torna-se mais complexo ao exigir-se dos alunos conhecimentos de diferentes campos discursivos e dos gêneros que os compõem. A compreensão solicitada nessa etapa recai sobre práticas de letramento nas quais eles não foram formados e não possuem autonomia para realizar. 
No terceiro ciclo, os alunos deparam com um professor que pretende ensinar o conteúdo pertinente à sua disciplina, tornada o centro da atenção e o esforço empreendido pelo professor no ensinado. A leitura e a escrita tomam outro valor e aspecto na nova dinâmica da sala de aula: falar, ler e escrever centram-se e movem-se na direção da disciplina. No tempo destinado a ela, o professor foca-se na História e em seus sub-temas, fio condutor do ato de ensinar e, assim, falar, ler e escrever ficam a serviço do ensino de História.

O terceiro ciclo promove uma ruptura fundamental na dinâmica do uso da fala, leitura e escrita, isto é, nas práticas de letramento. O que era o centro e os esforços do professor e do aluno nas séries iniciais muda de configuração. Oralidade, leitura e escrita não são mais o objeto a ser apreendido, mas tornam-se o instrumento para aprender a disciplina, isto é, não se estuda para aprender a falar, ler e escrever corretamente, agora se fala, lê e escreve para aprender, em nosso caso, História. É uma mudança paradigmática brutal no sentido do ensino e da aprendizagem.

O professor especialista em História sabe seus conteúdos, contudo a maioria não sabe ensinar sua disciplina em uma perspectiva letrada, ignorando que o aluno que está à sua frente não foi iniciado na forma específica de História que está sendo falada, ouvida, lida e escrita em sala de aula. Sobretudo no $6^{\circ}$ ano de escolaridade, esse professor provavelmente é o primeiro historiador que o aluno conhece e a primeira vez que depara com tal estética composicional. Assim, o “jeito" de falar, ler e escrever desse professor é exótico para o aluno. Em suma, podemos dizer que o $6^{\circ}$ ano de escolaridade é o momento de iniciação na leitura da historiografia, o primeiro contato imediato com um historiador e com a sua forma de pensar, fazer, falar e escrever a História.

Além de se exigirem conhecimentos que a formação acadêmica na Licenciatura de História não oferece ao professor, a História ensinada no $6^{\circ}$ ano do ciclo apresenta-lhe desafios específicos, que não serão oferecidos nos outros anos. O professor depara com um desafio, por exemplo, a que poucas pesquisas se dedicaram a investigar: a relação entre "ensino de" e o letramento escolar. Pesquisas nessas áreas encontram-se em processo embrionário e, sendo assim, disciplinas na formação pedagógica que se dediquem a discutir tal questão no ensino de História são incipientes, senão nulas. Diversos cursos de Bacharelado e Licenciatura não possuem disciplinas que dialoguem com as questões do letramento, salvo algumas iniciativas particulares de professores e departamentos que são desafiados a pensá-las.

A tarefa do ensino torna-se uma ação solitária e exploratória, uma vez que cada professor vai tateando e buscando formas de desenvolver oralidade, leitura e escrita em sua sala de aula de História. Nessa busca de soluções para as práti- 
cas desenvolvidas no ambiente escolar, os professores mobilizam seus saberes, tomando decisões que julgam cabíveis e eficientes para o desafio à sua frente. (MONTEIRO, 2007).

\section{Nossa pesquisa na sala de aula de História}

O paradigma indiciário nos municiou de um instrumental metodológico que possibilitou adensar a análise perspectivada ${ }^{1}$ da realidade complexa constituinte das múltiplas facetas do espaço concreto da sala de aula de História. A singularidade de cada indício ${ }^{2}$ nos proporcionou analisar o conjunto, assim configurando o ensinado a partir dos procedimentos analíticos empregados em nossas interpretações do campo de pesquisa. Os indícios, em suas singularidades, a nosso ver, diferenciaram cada evento, cada cena entre si, e, no complexo relacional que as compunha, propiciaram lentes metodológicas que balizaram a compreensão e a caracterização dos significados da História ensinada, os quais se constituíam via práticas de letramento. Salientamos que a singularidade dos indícios se forma na intersubjetividade, isto é, nas relações dos indivíduos com tempo-espaço sócio-histórico, pois os indícios são parte dos eventos e, dessa forma, estão localizados em um todo mais complexo, constituído de múltiplas individualidades que se estruturam em relações históricas e sociais.

Nossa pesquisa é de inspiração etnográfica, pois buscamos compreender o processo da História ensinada, imerso na sala de aula e em suas relações, situado nos processos históricos que a constituem. Para tanto, o uso da videogravação nos ajudou a ver e rever os acontecimentos, adensando nossa descrição e narrativa.

A câmera fixada no tripé foi colocada ao final da sala de aula, já que a sua posição focava a ação do professor. Os alunos, organizados em filas duplas, aparecem de $\operatorname{costas}^{3}$ e, dessa forma, são atores coadjuvantes ${ }^{4}$. Vale destacar que, como o nosso objetivo era investigar o ensinado, a forma como o professor

\footnotetext{
${ }^{1}$ Em diálogo com o arcabouço teórico que nos sustenta, compreendemos a realidade sempre como perspectivada, isto é, dimensionada sobre o prisma do tempo-espaço sócio-histórico que a constitui enquanto materialidade complexa, forjando as lentes conceituais do pesquisado e sendo sustentáculo para as argumentações tecidas e as compreensões urgidas.

2 “Os diferentes aspectos da enunciação podem ser sutilmente postos em evidência. Não é apenas o seu sentido objetivo que é apreendido, a asserção que está nela contida, mas também todas as particularidades linguísticas da sua realização verbal" (BAKHTIN; VOLOCHINOV, 2002, p. 154, grifo nosso).

${ }^{3}$ A estratégia de produção de indícios buscou garantir o anonimato dos alunos os quais, com idade média de 12 anos, frequentavam a sala de aula da pesquisa.

${ }^{4}$ Afirmamos que não negamos o protagonismo dos alunos. Nossa metodologia de produção de dados tinha como objetivo focar o ensinado e, dessa forma, os eventos na História ensinada estavam posicionados de forma a destacar e salientar a ação do professor. Nessa perspectiva, o aluno torna-se o coadjuvante, o ambiente situado e condicionante da ação do professor, mas não o centro de nossa atenção e foco do nosso olhar.
} 
organiza as práticas de letramento e, em um segundo momento, a produção de sentido na História ensinada, esse último aspecto tornou-se um elemento fundamental em nossa investigação.

Salientamos que não estamos negando a participação essencial do aluno no processo de construção de sentido na História ensinada, porém nossa opção metodológica e nosso foco de olhar se direcionam ao professor. $\mathrm{Na}$ verdade, buscamos compreender como esse sujeito do processo mobiliza saberes e fazeres na produção de sentido na História ensinada, tendo as práticas de letramento como elemento central do olhar e deflagrador das ações e significações tecidas.

O vídeo acabou por dimensionar o campo de outra forma e permitiu que, em alguns momentos, nosso olhar perdesse sua centralidade no professor, pois os nossos olhos podiam vaguear pela sala, observando os alunos e seus movimentos e implicando rápidas anotações no caderno de campo. Entretanto, a câmera, "fiel escudeira", encontrava-se em seu tripé focada e registrando o nosso centro de investigação - o professor ensinando. Por fim, essa experiência apresentou-se como um duplo registro de campo, ao ampliar nosso escopo de análise e adensar nossa compreensão sobre aquele lugar situado.

$\mathrm{O}$ vídeo nos possibilitou rever alguns gestos, olhares e silêncios, acontecimentos que, no momento do registro, passaram despercebidos, mas, na produção e análise dos indícios, saltaram aos olhos. Esse instrumental técnico também nos liberta em alguns momentos para olharmos o periférico - $\mathrm{o}$ aluno que mexe com a colega, a borracha que é trocada, o livro que cai da mesa, e tantos outros acontecimentos que compõem o cenário da sala de aula.

A busca por interferir o mínimo possível é um desejo utópico de vários pesquisadores. O fato de estarmos naquele lugar impossibilitou tal pretensão, visto que influenciou a "naturalidade" dos acontecimentos. Ao mesmo tempo, com o passar dos dias, nossa presença se tornou parte da "paisagem" e foi sendo naturalizada pelos personagens que compunham o quadro escolar naquela sala. Observamos que, no transcorrer da aula, gradualmente fomos sendo ignorados e, somente quando algo "saía" do esperado, nossa presença tinha ação direta sobre a condução do ato: ela era valorizada e as ações eram produzidas de forma estudada e condicionada pela presença do olhar do "estrangeiro" e do registro mecânico da câmera de vídeo.

O filme e os recortes dos eventos e das cenas que construímos para analisar, interpretar e categorizar não podem ser chamados de expressão exata da História ensinada na turma pesquisada. Nosso "filmico" é uma representação textual-imagética do tempo-espaço sócio-histórico situado com enquadramento

\footnotetext{
${ }^{5}$ Não acreditamos que a aula seja de constituição "natural". Esse espaço social se estrutura em relações de luta, hierarquia e poder. Ao adjetivarmos como "natural", queremos destacar que o ritmo cotidiano tradicional é rompido com a presença do pesquisador e de suas tecnologias de registro.
} 
e foco, o que compromete assim, muitas vezes, o olhar periférico que constitui a totalidade. O que é a totalidade senão a possibilidade complexa de compreensão de um hipotético "todo"? Nessa perspectiva, nossa pesquisa, limitada pelas circunstâncias, buscou uma compreensão analítica e complexa de nossa possibilidade do "todo", relativa ao instrumental técnico, analítico e conceitual. Sendo assim, nossa narrativa/argumentação, que visa promover um potencial "sentido" produzido na sala de aula investigada, é um constructo linguístico permeado de pretensões de validez.

O processo de captação dos vídeos se constituiu gradativamente. Antes de iniciarmos a captação das imagens, realizamos um encontro com a turma, explicamos como ocorreria a investigação e mostramos o equipamento e o lugar onde ficaria. No primeiro dia de filmagem na sala de aula, nossa presença criou certo alarido: os alunos volta e meia olhavam para a câmera e alguns até acenavam. No entanto, com o decorrer dos dias, nossa estada deixou de produzir interesse e nos tornamos quase uma mobília na sala.

Estivemos em campo no período de fevereiro a julho de 2009, indo a todas as aulas, e, no segundo semestre, no período de agosto a dezembro do mesmo ano, fizemos mais três visitas esporádicas as quais visavam apenas observar se o ritmo estabelecido permanecia. Nesse segundo período, nossa presença causava várias modificações no cotidiano, já que éramos um visitante conhecido que retornava depois de um longo tempo afastado, isto é, não éramos mais a mobília no final da sala e causávamos um impacto, para nós indesejado. Esses fatos contingenciaram nossa ação na pesquisa e nos fizeram lembrar o quanto modificamos com a nossa investigação o cotidiano da sala pesquisada.

Como a realidade se transforma com a nossa presença, tal fato nos faz afirmar que "todo" indício empírico é uma perspectiva circunstanciada da realidade e, como tal, está impregnado de seu situado discursivo e da validade que os pares darão ou não ao seu constructo. Dessa forma, é inegável a plasticidade que a pesquisa sofre em sua composição e também a estética alterada do campo com a presença e o olhar do pesquisador. Logo, seja qual for a metodologia, os "dados" sempre serão uma face destacada do real, pois são indícios e não o real reproduzido. Acreditamos ser impossível que a realidade seja reproduzida, analisada e categorizada em sua totalidade. Ocorre que a pesquisa apresenta uma possibilidade de compreensão analítica do espaço vivido e, assim, uma face circunstanciada pela lente teórica, conceitual e intersubjetiva do pesquisador.

Apresentamos essa breve reflexão para destacar o quanto nossa própria produção, uma vez imersa no mundo da vida e nas relações de poder, sofre em sua produção de sentido. Por conseguinte, convidamos você, leitor, a singrar o caminho que trilhamos e esperamos que, ao final, nossas pretensões sejam validadas. 
$\mathrm{Na}$ seção a seguir, trazemos para o debate uma cena da História ensinada ${ }^{6}$, na qual buscamos exemplificar e aprofundar as questões que estamos entabulando em nossa argumentação.

\section{Cena em foco}

A cena é um fragmento da aula do dia 19 de abril de 2009, que possui como "pano de fundo" a correção do simulado?. O simulado é uma prática de letramento permeada pela cultura escolar situada da instituição pesquisada, ocorre há vários anos e está marcado pelas relações sócio-históricas que o circunstanciam. Além disso, essa escola também possui, em seus elementos estruturantes, práticas tradicionais de letramento vinculadas à tradição avaliativa de controle social da aprendizagem.

A escola pesquisada realiza um sistema de avaliação bimestral concentrada, isto é, todos os alunos do $6^{\circ}$ ao $9^{\circ}$ ano são submetidos juntos às provas de um bloco específico de disciplinas em um único dia: os alunos são organizados em fileiras alternadas entre um ano de escolaridade e outro; os professores, dividindo-se para a aplicação da prova, podem ou não ser responsáveis pelo ensino da disciplina avaliada; as provas são obrigatoriamente de múltipla escolha e iguais para todas as turmas, de acordo com a disciplina e o ano de escolaridade; e a correção é realizada pelo professor da turma. $\mathrm{Na}$ referida escola, esse ritual é denominado simulado e corresponde a $50 \%$ do conceito do aluno no bimestre.

O simulado caracteriza-se como uma prática de letramento escolar situada, que possui nessa escola o objetivo de formar os alunos para as avaliações às quais eles são submetidos ao longo de sua formação. As avaliações em questão são aplicadas e sistematizadas pelo Estado - seja na esfera estadual ou federal - e também classificam as escolas, servindo como um dos instrumentos que definem as verbas destinadas e os abonos salariais dos professores.

A organização da escola é profundamente atingida por uma demanda externa de mensuração e ranqueamento, a que as escolas públicas brasileiras estão submetidas atualmente. Tal realidade sócio-histórica e econômica produz práticas que visam dar sustentação e alternativas de enfrentamento ao desafio embutido nesse processo, produzindo assim diversos conhecimentos manifestos e ocultos que permeiam o ensinado e o aprendido.

O simulado é organizado pela equipe de professores de cada disciplina e de cada ano de escolaridade, isto é, os professores de História do $6^{\circ}$ ano

\footnotetext{
${ }^{6}$ O campo apresentado neste artigo foi produzido de março a dezembro de 2009, em uma Escola Estadual do Estado do Rio de Janeiro/Baixada Fluminense.
}

${ }^{7}$ No corpo do texto a estruturação do simulado é apresentado. 
coletivamente, ou revezando, organizam as questões e a confecção do simulado. No primeiro bimestre do ano de 2009, a prova foi elaborada pelo professor Caio.

\section{Fontes Históricas}

\begin{tabular}{|c|c|c|}
\hline Emissor & Enunciados* & Fala \\
\hline Breno** $^{* *}$ & 1 & Vestigios deixados pelos homens... \\
\hline Caio $^{* * *}$ & 2 & $\begin{array}{l}\text { Isso, são vestígio deixados... fala [indica que um aluno fale novamente, } \\
\text { o áudio não registra a resposta do aluno]. } \\
\text { Isso... são vestígios deixados pelo homem do passado que servem para a } \\
\text { gente poder estudar. } \\
\text { Essa é uma definição rápida... curta e rápida... Nééé... } \\
\text { O que são fontes históricas? / Xiu/... Todo tipo de vestígio... } \\
\text { Ééé... Aí na letra "a" e na letra "b", eu coloquei se elas são fontes históricas } \\
\text { escritas, } \\
\text { ou não escritas... } \\
\text { Galera olha só... teve gente que confundiu... TEVE GENTE QUE } \\
\text { CONFUNDIU... } \\
\text { Colocando onde fontes históricas...ééé... que eram não escritas nas escritas... } \\
\text { e vice-versa ... } \\
\text { O que é uma fonte histórica não escrita? } \\
\text { Dê um exemplo que não esteja aí na prova... }\end{array}$ \\
\hline Beatriz $z^{* * * *}$ & 3 & Um ferro... \\
\hline Carolina $^{* * * * *}$ & 4 & Ferro a carvão... \\
\hline Fernanda ${ }^{* * * * * *}$ & 5 & $U m C D \ldots$ \\
\hline Caio & 6 & $\begin{array}{l}\text { Carvão... [esboça um breve sorriso em relação à resposta carvão]. } \\
\text { Carvão não sei... Ferro se for trabalhado pelo homem... néée... Uma espada } \\
\text { de ferro... [vai se aproximando do grupo de alunas que estão } \\
\text { participando com mais intensidade da aula, naquele momento]. } \\
\text { Ab! O ferro a carvão... beleza... O ferro a carvão... beleza... É uma fonte } \\
\text { histórica não escrita... beleza!?... } \\
\text { É todo e qualquer objeto que a gente não pode [faz o gesto de escrita na } \\
\text { folha que está na sua mão]... }\end{array}$ \\
\hline
\end{tabular}

\footnotetext{
* Compreendemos que o enunciado traz em si um acabamento e abre um espaço de contrapalavra, seja do próprio professor seja de outro participante da aula. A divisão efetivada na transcrição das falas apresenta esta perspectiva.

** Nome fictício - aluno.

*** Nome fictício destinado ao professor da sala de aula pesquisada.

**** Nome fictício - aluna.

***** Nome fictício - aluna.

${ }^{* * * * * *}$ Nome fictício - aluna.
} 
Figura 1 - Sala de aula de História

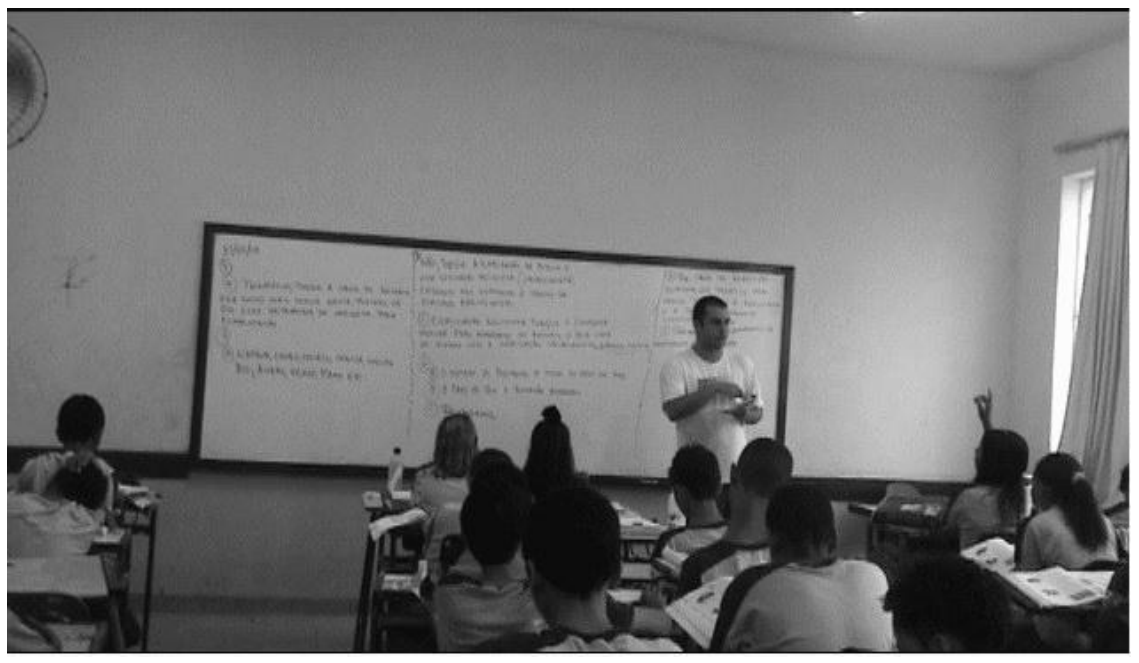

Fonte: Patricia Bastos de Azevedo. Arquivo pessoal.

Na cena "Fontes históricas", a questão do estilo historiográfico é fundamental. Isto é, algumas palavras e expressões ganham um significado diferente do encontrado no cotidiano que os alunos vivem, criando um sentido de individualidade próprio na História ensinada e mesclando traços estilísticos das práticas de letramento da historiografia e do próprio estilo que o professor constrói no ensinado.

[...] o estilo é o conjunto de traços fônicos, morfológicos, sintáticos, semânticos, lexicais, enunciativos, discursivos etc., que definem a especificidade de um enunciado e, por isso, criam um efeito de sentido de individualidade. [...] O estilo é o conjunto de particularidades discursivas e textualidades que cria uma imagem do autor, que é o que denominamos efeito individualidade. [...] O estilo é o resultado de uma visão de mundo. Assim como a cosmovisão estrutura e unifica o horizonte do ser humano, o estilo estrutura e unifica os enunciados pelo enunciador. (FIORIN, 2008, p. 46-47).

As expressões "fontes históricas", "vestígios", "arco e flecha" e "pirâmides" vêm carregadas de significados que se incorporam de sentidos na História ensinada. No simulado, a questão solicita dos alunos uma compreensão de múltiplas informações e certa capacidade de trânsito pelo vocabulário usado na História.

[...] qual o traço comum que permite chamar de fontes para o conhecimento histórico coisas tão díspares como uma estátua grega do século V a.C., uma 
máscara maia, uma carta do Marquês de Pombal, um concerto de Mozart, uma película cinematográfica, um artigo de jornal sobre os perigos do desmatamento, uma entrevista gravada de um trabalhador em greve, uma fotografia e uma telenovela?A resposta está no interesse do historiador em inquirir o que essas coisas revelam sobre as sociedades às quais elas pertencem e na criação de uma narrativa explicativa sobre o resultado de suas análises. (JANOT'TI, 2006, p. 10).

Nessa cena, o professor busca aproximar um conjunto de $\operatorname{signos}^{8}$ do universo vocabular e compreensivo dos alunos. O desafio, além da compreensão da definição de "fonte" em uma perspectiva historiográfica escolar, era a necessidade de extrapolar a questão para sua especificidade, isto é, para a escrita e a não escrita. Não bastava compreender o sentido que "fonte" possui na História e em sua modalidade escolar; o aluno, na questão, deveria ser capaz de, a partir das imagens - apresentadas na prova em preto e branco -, distinguir as escritas das não escritas. É importante lembrar que o conteúdo do $6^{\circ}$ ano é Introdução à História e História Antiga e, logo, os exemplos contidos na avaliação eram imagens desse período.

Antes de iniciar a correção, o professor pergunta a definição de "fonte", o aluno Breno fala e o professor Caio repete - Isso, são vestígios deixados... -, salientando a resposta como correta. A fala [E:1] do aluno é uma resposta dada anteriormente pelo professor e escrita no caderno de História. Nessa resposta, observamos o uso de expressões típicas do vocabulário historiográfico, como "vestígios deixados", palavras que possuem uma carga de significação diferente da expressão "restos deixados". Historiador não pesquisa "restos", ele não interpreta "destroços". Sua ação é mais sofisticada e sua análise mais qualificada. "Restos" e "destroços", mesmo sendo do mesmo campo semântico que "vestígios", não possuem o mesmo grau de importância e não são expressões usadas no campo discursivo da História.

Mas a palavra não é somente o signo mais puro, mais indicativo; é também um signo neutro. Cada um dos demais sistemas de signos é específico de algum campo particular da criação ideológica. Cada domínio possui seu próprio material ideológico e formula signos e símbolos que lhes são específicos e que não são aplicáveis. O signo, então, é criado por uma função ideológica precisa e permanente inseparável dela. A palavra, ao contrário, é neutra em relação a qualquer função ideológica específica. Pode preencher qualquer espécie de função ideológica: estética, científica, moral, religiosa. (BAKHTIN, 2003, p. 37).

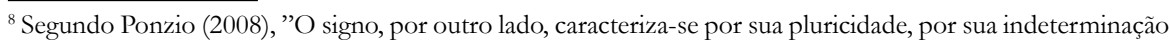
semântica, por sua fluidez expressiva e porque se adapta a situações sempre novas e diferentes" (PONZIO, 2008, p. 90).
} 
"Vestígios", "restos" e "destroços", em um contexto social diferente, poderiam possuir significados semelhantes, hierarquia e valoração distintas da adquirida nesse espaço ideológico. Na História ensinada, "vestígios" possuíam valor e aquilatamento distintos de "restos" e "destroços". Quando o professor [E:2] reconhece e aceita a resposta falada por Breno, ele está refletindo sobre o "campo de criação ideológico" em que o ensinado está imerso. Dessa forma, ele refrata os outros sinônimos que possuem uma sinalidade semelhante à palavra eleita como mais correta neste situado.

A prática de letramento que incorpora o uso da palavra reflete e refrata um campo ideológico, seu estilo e os gêneros discursivos que o compõem. Dessa maneira, a "palavra é o fenômeno ideológico por excelência" (BAKHTIN, 2002, p. 36).

A questão da prova possui um significado ideológico enquanto questão avaliativa e enquanto palavra que compõe um vocabulário de um campo de conhecimento discursivo - a História. Assim, a questão exige do aluno múltiplos conhecimentos e saberes e um reconhecimento prático do campo discursivo que forma o simulado.

Outro indício nessa cena se destaca - fonte escrita e não escrita. A palavra "fonte", assim como "vestígios", possui uma significação e uma importância hierárquica tanto na historiografia como na História ensinada. "Fonte", mais que um espaço físico que jorra água, na construção arquitetônica da História e em seus processos de legitimação e consolidação como ciência, assume múltiplos significados e status. Trata-se de uma "palavra" conflituosa e movediça, que apresenta em si disputas e espaços de legitimação.

Ginzburg (1989) propõe um paradigma que tem como perspectiva a busca e a construção de sinais - indícios. Isso muda a concepção de uma "prova" que revelaria o passado. Para esse autor, o historiador é comparado ao investigador e ao caçador, os quais buscam pistas e, assim, vão tecendo sua narrativa, construindo e dimensionando o passado. "O caçador teria sido o primeiro a 'narrar uma história' porque era o único capaz de ler, nas pistas mudas (se não imperceptíveis) deixadas pela presa, uma série coerente de eventos" (GINZBURG, 1989, p. 152). A palavra "fonte" possui a perspectiva do lugar de onde o historiador "bebe" e narra o passado da humanidade a partir de suas interpretações e categorizações.

A polêmica" entre "prova", "fonte", "vestígios" e "indícios" produziu um farto material de debate na História. A questão da escolha das palavras indica,

\footnotetext{
${ }^{9}$ [...] quando elaboramos seus relatos, eles [historiadores] na prática estão fazendo estudos comparativos. Se não enxergamos isso, se usamos a palavra "fonte" em lugar de "vestígios", se denominamos "primárias" almas daquelas fontes e se às vezes substituímos "primária" por "originais" (fontes originais e, portanto, subjacentes/fundamentais), isso dá a entender que, se formos aos originais, poderemos adquirir conhecimento verdadeiro/profundo, pois os originais parecem profundos (à diferença dos vestígios secundários, ou seja, de segunda mão) [...] (JENKINS, 2009, p. 79).
} 
de forma sensível, o posicionamento metodológico e a escolha de conceber a "verdade" e a "exatidão" do passado escrito. Tradicionalmente, a prova e o documento trazem em si uma concepção de pureza, clareza e exatidão, enquanto os vestígios trazem a idéia de algo difuso e embaçado e que necessita de lapidação para mostrar as feições, ligando a historiografia ao labor do historiador.

Fizemos essa breve digressão em relação à "fonte", "prova" e ao "vestígio", porque as três palavras possuem posturas metodológicas distintas e, em alguns momentos, opostas. $\mathrm{Na}$ aula de Caio, as duas palavras - fonte e vestígio são componentes do mesmo texto, sem antagonismo ou oposição e não há destaque à questão de esses dois termos serem distintos de "prova". Tal questão é fundamental quando destacamos a estética da composição da aula e suas práticas de letramento. A História ensinada ganha uma estética híbrida, mesclando várias escolas historiográficas e tendências filosóficas na construção de um texto que tem uma finalidade distinta do acadêmico. Nesse sentido, "fonte" e "vestígios" assumem função semelhante no exercício da pesquisa histórica.

O conhecimento escolar é, portanto, organizado de acordo com a lógica própria, educacional e escolar, e que atende a interesses e objetivos da sociedade onde essa atividade de ensino se realiza. As disciplinas são parte integrante e fundamental do processo de educação realizado nas escolas [...] (MONTEIRO, 2007, p. 95).

No ensinado, as palavras ganham uma discursividade diferente da História em sua perspectiva acadêmica, pois estão dimensionadas em outro foco e outro destinatário enunciativo. Sua proposta está estruturada em outra racionalidade discursiva, distinta da ciência de origem, com objetivos, estratégias e desenvolvimentos diferentes. Nessa cena, novamente, o grande desafio do professor é ensinar História e lidar com o contexto que o circunstancia, incluindo nesse processo o livro didático, o qual define fonte e vestígio como elementos semelhantes e com a mesma aquilatação.

O professor Caio encerra essa cena apresentando a questão - "É... neste exemplo são não escritas...", ou seja, ele fecha a cena apresentando que a "fonte" pirâmide, dependendo do olhar do historiador, poderá ser uma fonte escrita ou não escrita. Aponta, em sua fala, que esse elemento tão caro à História - as "fontes" - pode ser percebido de formas distintas por diferentes historiadores.

As palavras, nesse processo do ensinado, são usadas e significadas de diferentes formas tanto pelo professor como pelos alunos. No caso, a compreensão mútua é tecida no processo de explicação e no estabelecimento dos enunciados.

A imagem que o enunciador faz de seu interlocutor tem um acabamento, dado por um estilo. Por isso, o estilo também pode ser determinado pelo parceiro da comunicação. Assim, é diferente fazer um enunciado dirigido a um amigo 
ou a um desconhecido, a uma autoridade ou a um colega de trabalho, a uma criança ou a um adulto. (FIORIN, 2008, p. 48).

Em sua explicação, Caio busca verificar e compreender como os alunos entenderam as palavras "fonte", "escrita" e "não escrita". Os enunciados, que compreendem o intervalo de [3-6], caracterizam-se por um diálogo entre professor e alunos, buscando incorporar os exemplos dados pelos alunos à sua explicação. Essa forma de construir o enunciado possui um estilo típico do espaço da sala de aula, estilo que se diferencia dos debates acadêmicos. A explicação do professor é estruturalmente flexível, pois os alunos interpelam e transformam em coautoria a tessitura do explicado,o qual se realiza em ato único, efêmero e "irrepetível".

Nessa cena, o professor busca uma síntese para o conteúdo que está ensinando. Quando Breno define "fonte", Caio usa sua definição, mas destaca - Essa é uma definição rápida... curta e rápida... Nééé... Nesse espaço social e com o auditório para o qual seu enunciado está sendo proferido, a definição cabe, assim como o uso de palavras do mundo da vida e de gírias - "galera" [E: 2] - que caracterizam um falar híbrido, falar este que oscila entre o campo discursivo da História, da educação escolar e da compreensão sobre os alunos que compõem a sala de aula.

As práticas discursivas possuem um estilo e uma estética que refletem os diversos campos discursivos que constituem o ensinado, como também refratam diversas palavras e enunciados de tais campos.

\section{Diante do desafio de ensinar História}

Diante do desafio de ensinar, os professores acabam por repetir práticas tradicionais ou buscar solitariamente ações que possibilitem o processo de ensinar por tentativa e erro. Não compreendemos a escola como o único lugar de letramento e muito menos de conhecimento e apropriação de leitura e escrita que permeia a História. O que queremos salientar é que a escola é um espaço privilegiado de difusão do conhecimento histórico a partir da historiografia escolar. Muito embora a escola não seja a única agência de letramento em nossa sociedade, é certo que ela tem sido a responsável por colocar crianças, jovens e adultos em contato com a ciência de maneira sistematizada e intencional.

A construção de sentido histórico na História ensinada exige do professor um exercício que transita entre História, oralidade, leitura e escrita. Nessa busca por dar sentido à História ensinada, o professor faz um percurso didático que perpassa pela sua compreensão historiada disciplina e pelos subsídios que ele possui, pela cultura letrada que permeia a historiografia acadêmica e escolar e pela compreensão situada do tempo-espaço em que a sua sala de aula está inserida. 
Nesse sentido, quando afirmamos que a historiografia é uma prática de letramento, estamos também destacando que o ensino de História é atravessado pelas questões de oralidade, leitura e escrita presentes nesse constructo científico. Logo, ensinar História em qualquer nível escolar é letrar o aluno em História, desafio que se amplia no $6^{\circ}$ ano do Ensino Fundamental, pois os alunos veem pela primeira vez essa prática de letramento: a historiografia escolar.

A historiografia escolar se constitui em bases diferentes se comparada à escrita da História no processo constituído pelo historiador e por correlações de poder distintas. Entretanto, não estamos afirmando que o texto do livro didático ou a escrita no quadro realizada pelo professor não são historiográficas, apenas estamos salientando que as bases que os compõem possuem diferenças consideráveis em relação à historiografia acadêmica.

Pensar História ensinada e letramento demanda reflexão e diálogo com os campos da linguagem e do currículo, permeados pelas questões inerentes à disciplina, sua escrita e suas práticas na História ensinada. Ensinar História requer de seus agentes promotores uma relação com o mundo da vida e, logo, a construção de sentido se constitui como validade e valor no espectro situado do ensinado.

Rüsen (2001, p. 73) afirma que:

A experiência do passado representa, nesse momento, mais que a matéria-prima bruta de histórias produzidas para fazer sentido, mas algo que já possui, em si, a propriedade de estar dotado de sentido, de modo que a constituição consciente de sentido da narrativa histórica se refere diretamente a ela e lhe dá continuação (decerto com todos os demais ingredientes que as operações conscientes do pensamento histórico engendram). O passado precisaria poder ser articulado, como estado de coisas, com as orientações de sentido, com as quais o agir humano organiza suas intenções e expectativas no fluxo do tempo, precisam também elas estar dadas como um fato da experiência.

Fazer sentido na História ensinada requer mais que um conhecimento da matéria a ser ensinada; requer do professor uma imersão no tempo-espaço que constitui a sala de aula e as nuances que o ineditismo em ato exige cotidianamente. Nesse viés, conhecer o mundo da vida de seus alunos é fundamental na construção de suas explicações, pois possibilita que a escolha discursiva venha impregnada de significados de partida e agregados, elementos essenciais na estruturação das práticas de letramento que se constituem no ensinado.

A construção das analogias típicas da narrativa/argumentação histórica que marca a estética da historiografia na história ensinada, solicita do professor um conhecimento situado denso. $\mathrm{O}$ movimento de presente-passado-presente na construção de sentido histórico se complexifica no ensinado, tendo em vista que cada sala e cada aula trazem consigo um grau de ineditismo considerável. 
O processo de ensino está submetido a múltiplos procedimentos e, entre eles, estão os avaliativos - não é por acaso que Caio destaca o conteúdo "fonte". Diante de um fato consumado - o simulado e o conteúdo tradicional tratado no $6^{\circ}$ ano de escolaridade do Ensino Fundamental -, o professor utiliza a aula para ensinar e fixar os conteúdos que compõem os processos avaliativos do tempo-espaço em que está inserido. São as contingências que agem com forte impacto sobre o ensinado e tornam a ação do professor um fazer que caracteriza-se por sua autonomia parcial e flexível e por ineditismos circunstanciados pelo imperativo do situado.

Vale frisar a autonomia, pois, mesmo submerso em condições que lhe tolhem e condicionam o seu planejamento, o professor possuía outras alternativas na condução de sua aula, podendo escolher ir por outra direção, mas ele faz uma opção "lógica" e "prática", segundo sua compreensão ${ }^{10}$. O conhecimento dos condicionantes e do processo em que o ensinado está imerso "conduz", de certa forma, a escolha estética e as práticas de letramento que se desdobram na referida cena. Caio mira o simulado, seu conteúdo e formato, buscando preparar cotidianamente sua turma para a feitura da tarefa avaliativa.

O simulado talha fundamentalmente a face e as práticas que compõem o campo de pesquisa investigado. O instrumento avaliativo "local" possui uma dimensão e uma compreensão que vão além de sua aplicação por parte do professor e da comunidade escolar. O simulado é compreendido como um elemento de organização e propulsor de "elevação" da qualidade do ensino e da visão que a comunidade possui em relação à escola. Nesse sentido, em diferentes momentos, observamos o esforço coletivo da comunidade escolar destinada à "missão" de organizar e promover junto aos alunos a participação e a cooperação para a realização da prova.

\section{Breves conclusões}

As práticas de letramento que se constituem na História ensinada são significadas em seu contexto sócio-histórico; logo, falar, ler e escrever não podem ser analisados de forma isolada ou puramente quantitativa. Para compreender tais práticas, é necessário compreender os sentidos produzidos de forma contextualizada, pois as enunciações são impregnadas de coisas presumidas e não ditas, elementos estes compreendidos na vivência de produção do ato discursivo.

As atividades de letramento na História ensinada são configuradas nesse todo relacional. Os atos de ler o livro, copiar do quadro, escrever no caderno e responder a prova são contextualizados na vida escolar. Seus sentidos e suas significações enunciativas são de natureza social; dessa forma, é no contexto social que os sentidos são produzidos e sua validade é aceita.

\footnotetext{
${ }^{10}$ Caderno de campo - em conversa com a pesquisadora depois da aula, o professor aponta essa questão.
} 
As práticas em questão possuem uma singularidade significativa do tempo-espaço que as constitui de sentido e validade - o aqui e o agora que fomentam a capacidade responsiva do enunciado -, porém não podemos esquecer que esses elementos do ato em si estão posicionados historicamente. O reconhecimento do outro é fundamental para que a resposta ocorra, pois o enunciado conclama o outro para uma resposta, mesmo que esta seja o silêncio.

As práticas de letramento, sejam na História ensinada sejam no mundo, são circunstanciadas e validadas pelo contexto de vida, não podendo ser analisadas, categorizadas ou compreendidas fora da produção de sentido que as constitui e estrutura seus atos. Em virtude disso, são sempre sociais e marcadas pelo tempo-espaço que as compõe enquanto materialidade e validade. No caso, na História ensinada, são constituídas pela perspectiva escolar, histórica, social e filosófica que recobre seus atos e, assim, os sentidos produzidos em práticas de letramento.

As rotinas que compõem a sala de aula, como o letramento, nosso foco e centro de pesquisa, relacionam-se com questões de ordem mais ampla. A escola, nessa perspectiva, produz conhecimentos para a sociedade, mas também responde a solicitações e intervenções desse caldo social em que está imersa e estruturada.

A aula não se realiza em um espaço isolado - a sala de aula -, mesmo que esse espaço físico esteja limitado por quatro paredes e a portas fechadas. A sala de aula é espaço de passagem de múltiplas questões sociais e históricas que constituem e estruturam a escola, cujas práticas de letramento não estão isentas de relações de força e poder.

A aula apresenta regras e tradições que estão além do micro espaço que a compõe. Essas tradições constituídas nas escolas estão imersas em um tempo-espaço sócio-histórico, compostas pelo currículo em suas múltiplas dimensões.

Não há ensinado sem intenção e não há intenção que não esteja forjada no processo discursivo semiótico que permeia e interpenetra nossa inteligibilidade. Dessa forma, "[...] todo dizer não pode deixar de se orientar para o 'já dito'. Neste sentido, todo enunciado é uma réplica, ou seja, não se constitui do nada, não se constrói fora daquilo que chamamos hoje de memória discursiva [...]" (FARACO, 2009, p. 59, grifo do autor).

Podemos assim afirmar que todo ensinado está situado em um horizonte social e busca em sua composição interagir com seu "auditório social". O professor não constrói seu enunciado em sala de aula - sua explicação - sem um procedimento avaliativo que pressuponha uma resposta de seus alunos, e estes, "auditório social" que compõe a aula, direcionam a organização enunciativa do professor e sua potencialidade criadora e criativa. Dessa forma, "[...] todo dizer 
é internamente dialogizado: é heterogêneo, é uma articulação de múltiplas vozes sociais (no sentido em que hoje dizemos ser todo discurso heterogeneamente constituído) é o ponto de encontro e confronto destas múltiplas vozes [...]" (FARACO, 2009, p.60, grifo do autor).

A aula não se constitui isoladamente, pois está situada no mundo da vida e nas múltiplas vozes que a permeiam e a interpenetram. A aula se compõe, nessa perspectiva, como um gênero enunciativo carregado de tradições e "memórias discursivas", que constrangem e delimitam sua organização, estética e estrutura. Ao mesmo tempo, possui em si uma oferta de contra-palavra e de uma nova plasticidade possível, trazendo consigo "significados de partida" (PONZIO, 2008, p. 99), que originarão novas práticas enunciativas.

A construção de sentido no processo da História ensinada é a ação que mais consome os esforços dos professores e encaminha seus atos. Tendo essa afirmação como base, as práticas de letramento na História ensinada são contingenciadas por essa prerrogativa. Desse modo, oralidade, leitura e escrita na disciplina escolar História são o meio pelo qual o professor constrói sua narrativa/argumentação, buscando estabelecer uma relação entre presente-passado-presente, tecendo suas explicações e construindo o sentido histórico no ensinado.

Ensinar História na perspectiva que pensamos é um processo de letramento que o professor realiza transitando por práticas híbridas e construindo gêneros discursivos autênticos do espaço da sala de aula. É importante a ressalva de que os gêneros são difíceis de compreender e analisar, justamente porque habitam esse espaço cujo elemento fundamental de caracterização é o ineditismo em ato. Já que cada aula traz referências de outras aulas - significados agregados -, efetiva-se de forma única.

Como dito, a produção de sentido em práticas de letramento na História ensinada ocorre em uma perspectiva sócio-histórica. Nesse caminho, ao investigarmos a sala de aula que compôs a nossa pesquisa de campo, estávamos mergulhadas nesse todo relacional, contextualizado e validado pelo processo que o constitui enquanto ato. A aula de História se constitui em práticas de letramento, visto que a propagação da história acadêmica ou escolar se veicula via leitura e escrita e em práticas oralizadas mediadoras do escrito. Nesse sentido, a História ensinada em nossa sociedade grafocêntrica produz sentido em práticas de letramento que ousamos chamar de "letramento histórico". 


\section{Referências}

AZEVEDO, P. B. História ensinada: o tempo-espaço na produção de sentido. Revista Percursos, Florianópolis, v. 11, n. 02, p. 1-20, jul./dez. 2010.

AZEVEDO, P. B. História Ensinada: produção de sentido em práticas de letramento. 2001. 216 f. Tese (Doutorado em Educação) - Universidade Federal do Rio de Janeiro, Rio de Janeiro, 2011.

BAKHTIN, M. Questões de literatura e de estética (A teoria do romance). 4. ed. São Paulo: Unesp, 1998.

BAKHTIN, M. Marxismo e filosofia da linguagem. 9. ed. São Paulo: Hucitec/Annablume, 2002.

BAKHTIN, M. Estética da criação verbal. 4. ed. São Paulo: Martins Fontes, 2003.

CHARTIER, A. M. Escola, culturas e saberes. In: XAVIER L. N.; CARVALHO, M. C. de.; MENDONÇA, A. W.; CUNHA, J. L. (Orgs.). Escola, culturas e saberes. Rio de Janeiro: FGV, 2005. p. 9-28.

FARACO, C. A. Linguagem e diálogo: as ideias do círculo de Bakhtin. São Paulo: Parábola, 2009.

FIORIN, J. L. Introdução ao pensamento de Bakhtin. São Paulo: Ática, 2008.

GINZBURG, C. Sinais: raízes de um paradigma indiciário. In: GINZBURG, C. Mitos, emblemas e sinais: morfologia e história. São Paulo: Companhia das Letras, 1989. p. 143179.

JANOTTI, M. de L. O livro Fontes Históricas como fonte. In: PINSKY, C. B. (Org.). Fontes históricas. São Paulo: Contexto, 2006. p. 10-21.

JENKINS, K. A história repensada. 3. ed. São Paulo: Contexto, 2009.

MONTEIRO, A. M. F. C. da. Professores de História: entre saberes e práticas. Rio de Janeiro: Mauad X, 2007.

MORTATTI, M. do R. L. Educação e letramento. São Paulo: UNESP, 2004.

PONZIO, A. A revolução bakhtiniana. São Paulo: Contexto, 2008.

ROCHA, H. A. B. O lugar da linguagem no ensino de História: entre a oralidade e a escrita. 2006. 462 f. Tese (Doutorado em Educação) - Universidade Federal Fluminense.

RÜSEN, J. Razão da história: fundamentos da ciência histórica. Brasília: Editora Universidade de Brasília, 2001.

SOARES, M. Letramento e escolarização. In: RIBEIRO, V. M. (Org.). Letramento no Brasil: reflexões a partir do INAF 2001. 2. ed. São Paulo: Global, 2004. p. 89-113.

Recebido em 20/02/2013

Versão final recebida em 09/07/2013

Aceito em 05/08/2013 